\title{
A patient's perception of visual problems with epiretinal membrane formation and subsequent surgical interventions
}

\author{
Kashif Ali, ${ }^{1}$ Muhammad Usman Saeed, ${ }^{1,2}$ Sunildath Cazabon ${ }^{1}$ \\ 1'Department of Ophthalmology, Countess of Chester Hospital, Chester, Cheshire, UK; \\ ${ }^{2}$ St Pauls Eye Unit, Royal Liverpool University Hospital, Liverpool, Merseyside, UK
}

Correspondence to Mr Muhammad Usman Saeed, musmansaeed@aol.com

\section{DESCRIPTION}

We describe visual perceptions of a patient presenting with complaints of uniocular horizontal distortion and binocular central diplopia secondary to an epiretinal membrane (figure 1B,C). A pars plana vitrectomy, epiretinal and internal limiting membrane peel (double peel) was performed. Postvitrectomy, his central vision was distorted and pinkish (figure 1D). This improved, but he subsequently developed a cataract which caused a 'corona effect' and difference in colour perception (figure 1G). He underwent cataract surgery with intraocular lens implantation and then described his vision becoming 'blue tinged' (figure $1 \mathrm{~F}$ ). He then complained of 'diagnonal flare' with night driving. (figure 1E). This was attributed to posterior capsular thickening and he underwent laser posterior capsulotomy. The patient captured his perception of visual problems with the help of a camera and digital picture editing software.
This is a rare patient perspective of visual problems starting with a vitreoretinal procedure and the subsequent visual experience after multiple ocular procedures. Patients undergoing a pars plana vitrectomy often develop a cataract, which then necessitates cataract surgery. ${ }^{1} \mathrm{Nd}$-YAG laser capsulotomy may also be required in patients after cataract surgery. ${ }^{2}$

Visual perceptions have occasionally been documented by patients interested in the arts. ${ }^{3}$ With digital imaging and image manipulation by computer softwares becoming more common, patients can now express their visual problems in different formats. Pictures such as these may help treating ophthalmologists and primary care physicians understand the patient's visual problems and may also help other patients undergoing similar problems and procedures.

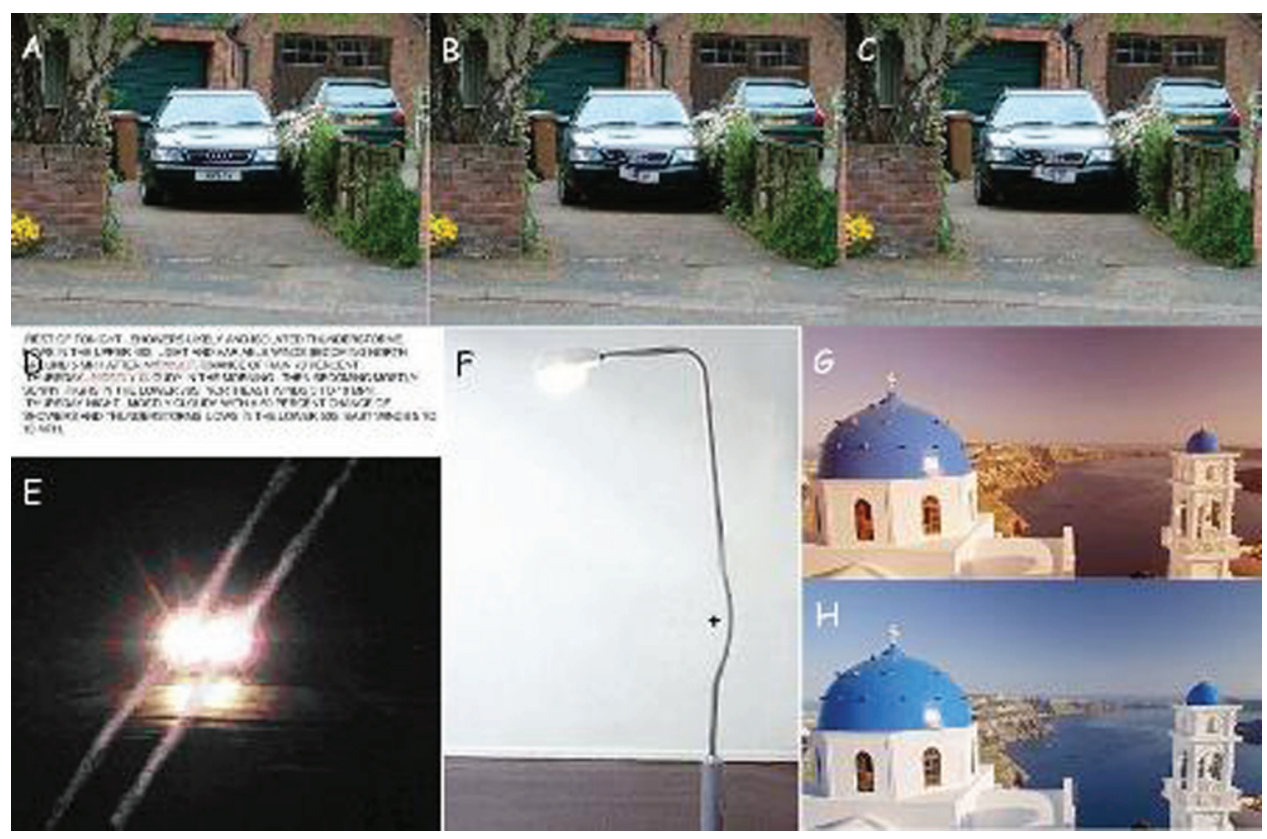

Figure 1 (A) Unaffected eye view. (B) Perception with affected eye before vitrectomy. (C) Binocular central distortion before vitrectomy. (D) Immediate postvitrectomy. (E) 'diagonal flare' described by patient after cataract surgery (due to posterior capsular opacification). (F) Current situation. (G) Before cataract surgery. (H) After cataract surgery. 


\section{BMJ Case Reports}

Acknowledgements The authors acknowledge the patient for providing digital images and his description of his visual experiences.

\section{Competing interests None.}

Patient consent Obtained.
2. Helbig H, Kellner U, Bornfeld N, et al. Cataract surgery and YAG-laser capsulotomy following vitrectomy for diabetic retinopathy. Ger J Ophthalmol 1996;5:408-14.

3. Zia R, Schlichtenbrede FC, Greaves B, et al. "Only rarely seen in dreams"visual experiences during cataract surgery. Br J Ophthalmol 2005;89:247-8.

\section{REFERENCES}

1. Petermeier K, Szurman P, Bartz-Schmidt UK, et al. Pathophysiology

of cataract formation after vitrectomy. Klin Monbl Augenheilkd

2010:227:175-80.

This pdf has been created automatically from the final edited text and images.

Copyright 2011 BMJ Publishing Group. All rights reserved. For permission to reuse any of this content visit

http://group.bmi.com/group/rights-licensing/permissions.

BMJ Case Report Fellows may re-use this article for personal use and teaching without any further permission.

Please cite this article as follows (you will need to access the article online to obtain the date of publication).

Ali K, Saeed MU, Cazabon S. A patient's perception of visual problems with epiretinal membrane formation and subsequent surgical interventions. BMJ Case Reports 2011;10.1136/bcr.05.2011.4253, date of publication

Become a Fellow of BMJ Case Reports today and you can:

- Submit as many cases as you like

- Enjoy fast sympathetic peer review and rapid publication of accepted articles

Access all the published articles

- Re-use any of the published material for personal use and teaching without further permission

For information on Institutional Fellowships contact consortiasales@bmjgroup.com

Visit casereports.bmj.com for more articles like this and to become a Fellow 